\title{
Managing Wireworms in Florida Sweet Potatoes ${ }^{1}$
}

\author{
Robert Hochmuth, Dakshina Seal, Norman Leppla, Daniel Fenneman, Rhoda Broughton, and \\ Anil Baniya ${ }^{2}$
}

\section{Introduction}

The purpose of this publication is to characterize sweet potato, Ipomoea batatas L., production in Florida and describe current methods for managing wireworms in this crop. It is intended primarily for growers and Extension agents. Wireworms, the larvae of click beetles, are the most damaging insect pests within a pest complex that includes insects that infest the foliage and roots. The primary foliage pests are several species of armyworms, Spodoptera spp.; agromyzid leafminers (fly larvae); the silverleaf whitefly, Bemisia tabaci (Gennadius); several species of tortoise beetles; and the morning glory leafminer, Bedellia somnulentella (Zell.), a small caterpillar that can build to very high populations in north Florida. Other insects that infest sweet potato roots include white grubs; the banded cucumber beetle, Diabrotica balteata LeConte; pale-striped flea beetle, Systena blanda Melsheimer; sweet potato flea beetle, Chaetocnema confinis Crotch; and, in south Florida, the Diaprepes root weevil, Diaprepes abbreviates (L.); and Cuban May beetle, Phyllophaga bruneri Chapin (https:// edis.ifas.ufl.edu/publication/ig159). However, wireworms and the sweetpotato weevil, Cylas formicarius elegantulus
(Summers), are the most damaging root pests, requiring surveillance for them in sweet potato. Sweetpotato weevils are important regulatory pests because shipping sweet potatoes outside of Florida has certain restrictions depending on the destination. Cultural practices, primarily soil tillage and crop rotation, can suppress populations of these root pests, but adequate management requires the use of insecticides. Due to a tenuous dependence on chlorpyrifos, research is being conducted on managing wireworms with alternative insecticide active ingredients. Entomopathogenic nematodes also are being evaluated.

\section{Florida Sweet Potatoes}

The sweet potato originated in Central America and is one of the oldest known vegetable crops in Florida. Producers in north Florida traditionally have planted small acreages of sweet potatoes for local markets but recently have begun to grow the crop for wholesale processors, chain stores, and other markets. It is estimated that the acreage of sweet potatoes in north Florida and south Georgia increased from a couple hundred acres to a few thousand acres beginning about 2015. Sweet potato acreage could continue to increase

1. This document is ENY-2068 one of a series of the Entomology and Nematology Department, UF/IFAS Extension. Original publication date September 2021. Visit the EDIS website at https://edis.ifas.ufl.edu for the currently supported version of this publication.

2. Robert Hochmuth, regional specialized Extension agent - northeast, UF/IFAS North Florida Research and Education Center Suwannee Valley; Dakshina Seal, research scientist, Entomology and Nematology Department; Norman Leppla, professor, Entomology and Nematology Department; Daniel Fenneman, county Extension director and Extension agent, UF/IFAS Extension Madison County; Rhoda Broughton, regional specialized Extension agent - northeast, UF/IFAS North Florida Research and Education Center Suwannee Valley; and Anil Baniya, graduate student, Entomology and Nematology Department; UF/IFAS Extension, Gainesville, FL 32611.

The use of trade names in this publication is solely for the purpose of providing specific information. UF/IFAS does not guarantee or warranty the products named, and references to them in this publication do not signify our approval to the exclusion of other products of suitable composition.

All chemicals should be used in accordance with directions on the manufacturer's label.

Use pesticides safely. Read and follow directions on the manufacturer's label.

The Institute of Food and Agricultural Sciences (IFAS) is an Equal Opportunity Institution authorized to provide research, educational information and other services only to individuals and institutions that function with non-discrimination with respect to race, creed, color, religion, age, disability, sex, sexual orientation, marital status, national origin, political opinions or affiliations. For more information on obtaining other UF/IFAS Extension publications, contact your county's UF/IFAS Extension office. U.S. Department of Agriculture, UF/IFAS Extension Service, University of Florida, IFAS, Florida A \& M University Cooperative Extension Program, and Boards of County Commissioners Cooperating. Nick T. Place, dean for UF/IFAS Extension. 
due to a unique early market "window" if product quality is not compromised by feeding injury from insect pests.

North Florida sweet potato fields are planted in late April, May, and June after spring temperatures have warmed sufficiently. Currently, most acreage is planted in standard, orange-fleshed cultivars, such as 'Covington' and 'Beauregard', and large-scale growers typically produce their own sweet potato beds with certified "seed" sweet potatoes for slip (transplant) production. Additionally, there is interest in planting other specialty varieties with different flesh and skin colors. Specialty sweet potato cultivars, such as 'Burgundy' and 'Palmetto', with production and marketing potential, are being evaluated at the UF/IFAS Hastings Agricultural Extension Center in Hastings, Florida. Harvesting usually begins in August and can continue well into the fall but usually is completed by mid- to late October. After harvesting, the sweet potatoes are cured without washing at about $30 \circ \mathrm{C}$ and $90 \%-95 \% \mathrm{RH}$ for at least a week, allowing time to heal the cuts and bruises that occur when they are harvested and transported to a packing house. The sweet potatoes are stored at $13 \mathrm{oC}-16 \mathrm{oC}$ and $80 \%-85 \% \mathrm{RH}$ after curing. The tubers are resistant to pathogens and shrinkage during storage, and starches are converted to sugars. The quality of the sweet potatoes for consumption is improved by curing and storage before they are graded, packed, and shipped.

In addition to the acreage of orange-flesh sweet potatoes in north Florida, a similar type of root crop known as a boniato is grown on a few thousand acres in south Florida. The boniato, also known as the Cuban sweet potato, has a white or lighter colored flesh that tends to be drier. The moist, orange-fleshed sweet potato grown in north Florida and the drier, white-fleshed type grown in south Florida both are taxonomically Ipomea batatas and have similar insect pests.

\section{Wireworm Pests of Sweet Potato in Florida}

The two primary pest species of wireworms that infest sweet potatoes in north Florida are Conoderus scissus (https://edis.ifas.ufl.edu/in911) and C. rudis (https://edis. ifas.ufl.edu/in909), C. scissus being the most abundant in 2016-18. The life cycle of C. scissus includes 7-10 instars over two to three years. Conoderus rudis has one generation per year. Recently, two other species, the Gulf wireworm, $C$. amplicolis (Gyllenhal), and the southern potato wireworm, C. falli (Lane), have been collected infrequently in sweet potato fields. These wireworms as a complex cause more injury to sweet potatoes than any other insect pest of this crop in north Florida. The injury results from feeding on the sweet potato roots. When feeding occurs early in the season and a root is relatively small and still expanding, the puncture wound heals, leaving a "knuckle-like" scar (Figure 1). However, late season punctures become unsightly circular holes in the sweet potato root (Figure 2).

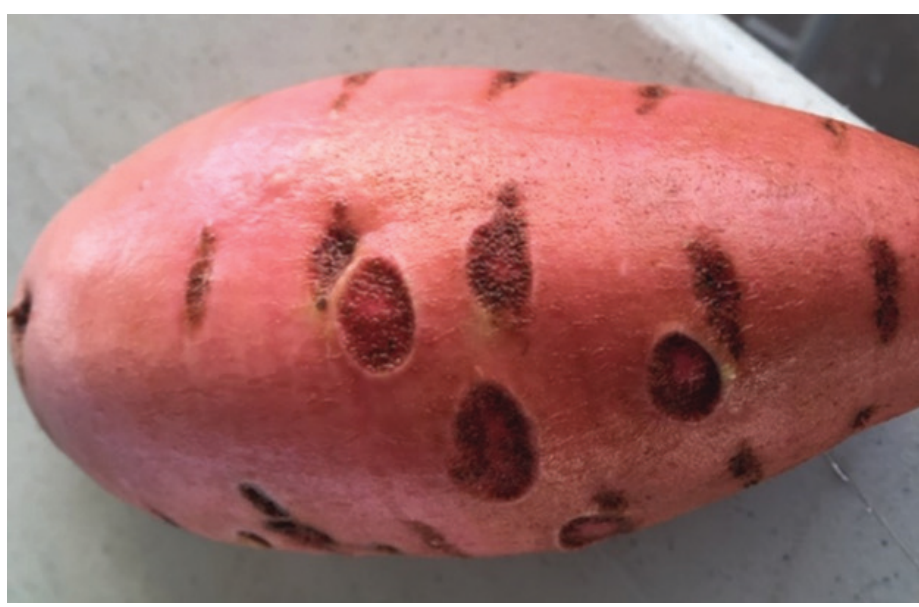

Figure 1. Wireworm injury caused by larval feeding early in the season when the sweet potato root was small. The symptom indicates root healing as the root increased in size.

Credits: R. Hochmuth, UF/IFAS

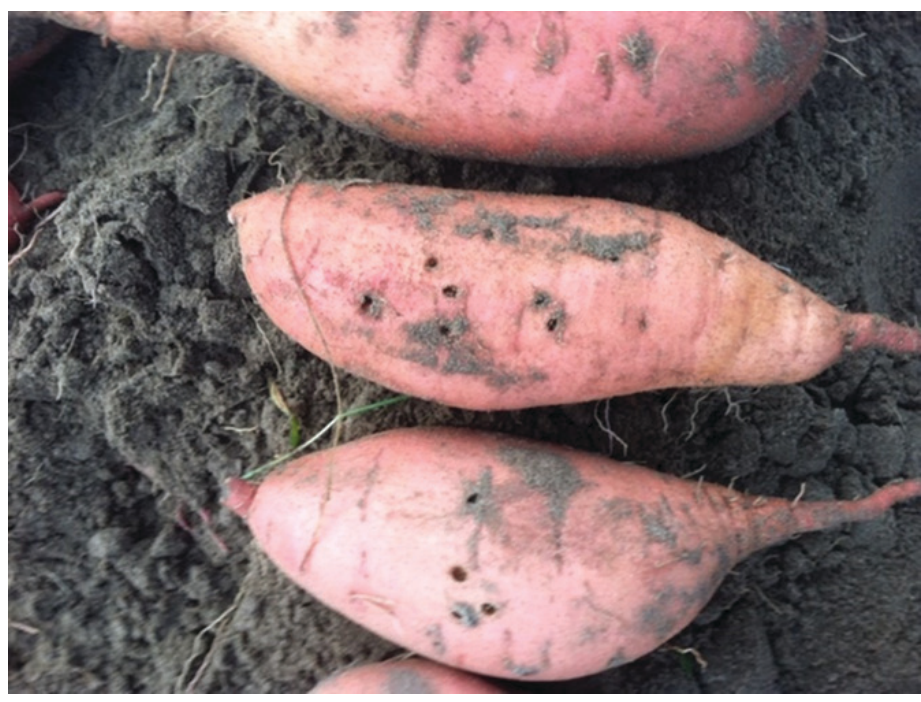

Figure 2. Circular holes typical of recent wireworm feeding injury on sweet potato roots that were already enlarged.

Credits: R. Hochmuth, UF/IFAS

\section{Click Beetle Monitoring Methods}

Click beetle population monitoring methods were evaluated at the UF/IFAS North Florida Research and Education Center-Suwannee Valley (UF/IFAS NFREC-SV) and used to determine beetle abundance during the 2016-2019 sweet potato production seasons in north Florida. Pitfall, yellow sticky card, and black light traps were tested by comparing the number of beetles they captured. Several designs of pitfall traps were tested with minimal success, and it was 
difficult to maintain the traps in a clean, dry, and functional condition (Figure 3).

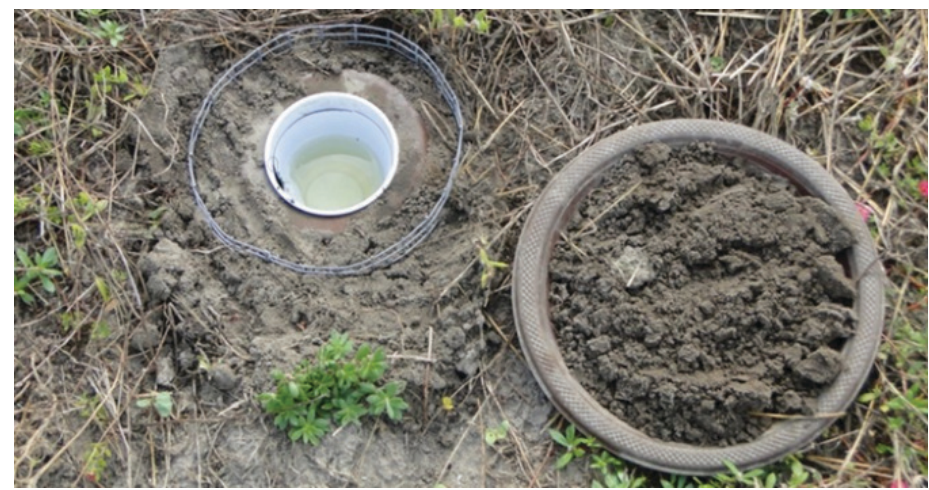

Figure 3. Examples of pitfall traps tested for collecting click beetle adults. A pit fall trap is used to collect ground-dwelling insects, such as click beetles, whereby the insect falls into the trap and is unable to escape.

Credits: R. Hochmuth, UF/IFAS

Yellow sticky card traps were evaluated by stapling a $15 \mathrm{x}$ $20-\mathrm{cm}$ card to each wooden stake and placing the traps around the perimeters of fields at several locations. The cards were positioned about one meter above the ground at least $30 \mathrm{~cm}$ above the sweet potato crop canopy (Figure 4). The yellow sticky traps were effective at attracting and catching click beetles but were very labor-intensive to deploy and examine, requiring frequent replacement due to damage from wind and blowing dust and sand (Figure 5).

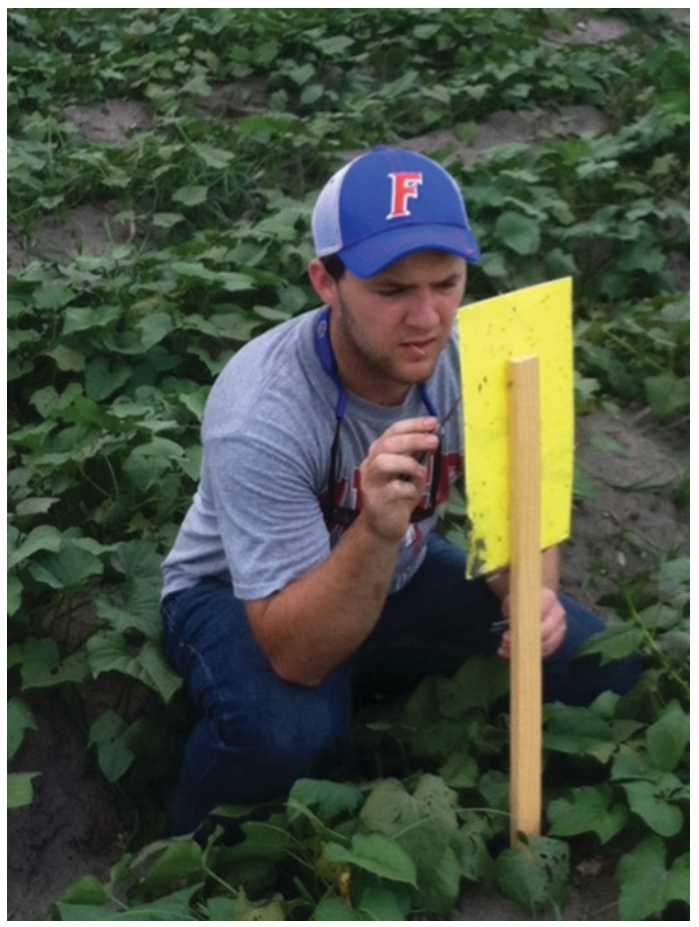

Figure 4. Yellow sticky card used to attract, trap, and monitor click beetle adults in a sweet potato crop.

Credits: R. Hochmuth, UF/IFAS

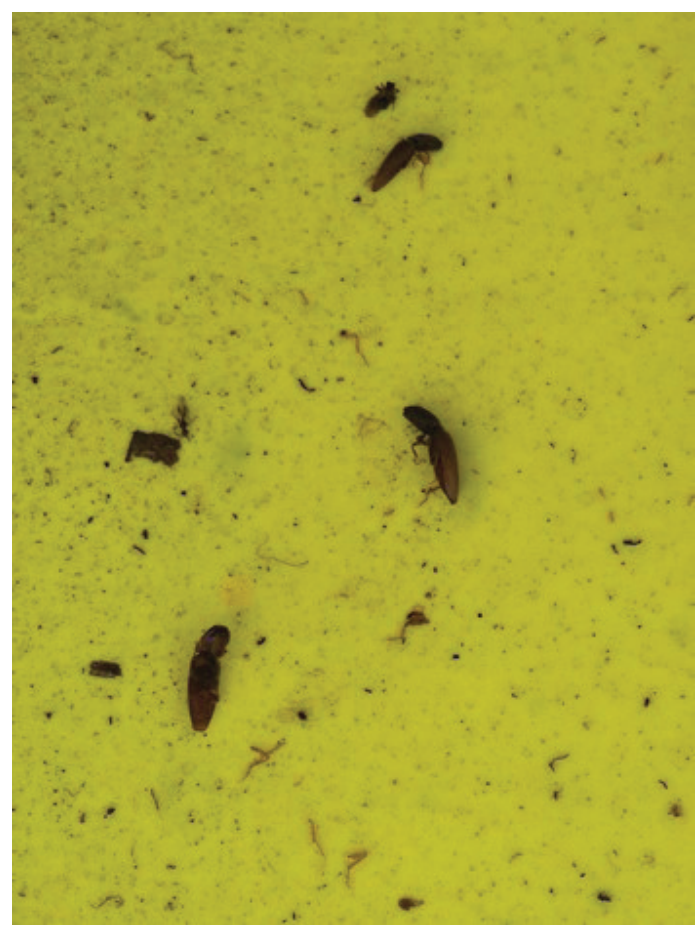

Figure 5. Yellow sticky cards that trapped three click beetle adults. Credits: R. Hochmuth, UF/IFAS

Commercially available black light traps designed to attract and capture flying insects at night, including click beetles, also were tested and used to monitor the beetles (Figure 6). These traps can be battery operated or connected to a permanent source of electricity and are very effective in attracting click beetles from moderate distances. A single black light trap can capture dozens of click beetles per night when populations peak. However, these traps are relatively expensive to purchase and operate; sorting through the collections is labor intensive; and the traps must be emptied at least 2-3 times each week. These traps were used to confirm that click beetles were active throughout the sweet potato season in north Florida from mid-April to the end of September. Although adults were abundant every month, click beetle activity peaked during May and June.

\section{Monitoring Wireworms in a Field before Planting a Sweet Potato Crop}

Sweet potato growers needed a method for estimating the abundance of wireworms in their fields before investing in a crop that could be severely damaged. Therefore, UF/IFAS researchers tested the effectiveness of wireworm seed-bait traps in fields during the fall before the spring sweet potato growing season. They evaluated a well-established method of attracting and capturing wireworms by burying a mixture of untreated corn seeds plus untreated wheat or oat seeds in a shallow hole in the soil. A post hole digger 
was used to make a 6-inch-deep round hole (Figure 7) into which $1 / 2$ cup of the 50:50 mixture of grain seeds was poured (Figure 8 ). The seeds were mixed with some of the soil in the bottom of the hole; the hole was covered with soil; and a flag stake was used to mark the location.

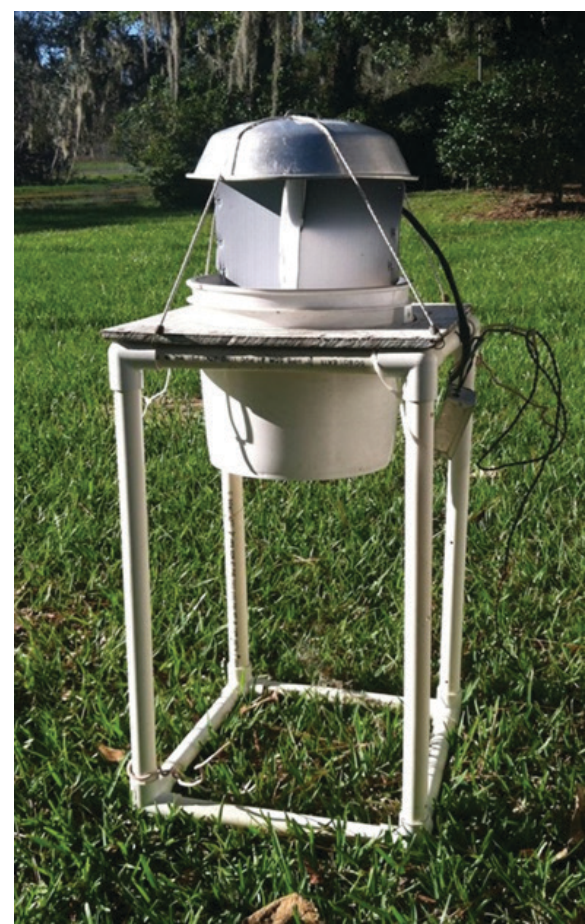

Figure 6. Black light trap for attracting and collecting click beetle adults at night. The electric light attracts adult click beetles, and a funnel below directs them into the bucket.

Credits: R. Hochmuth, UF/IFAS

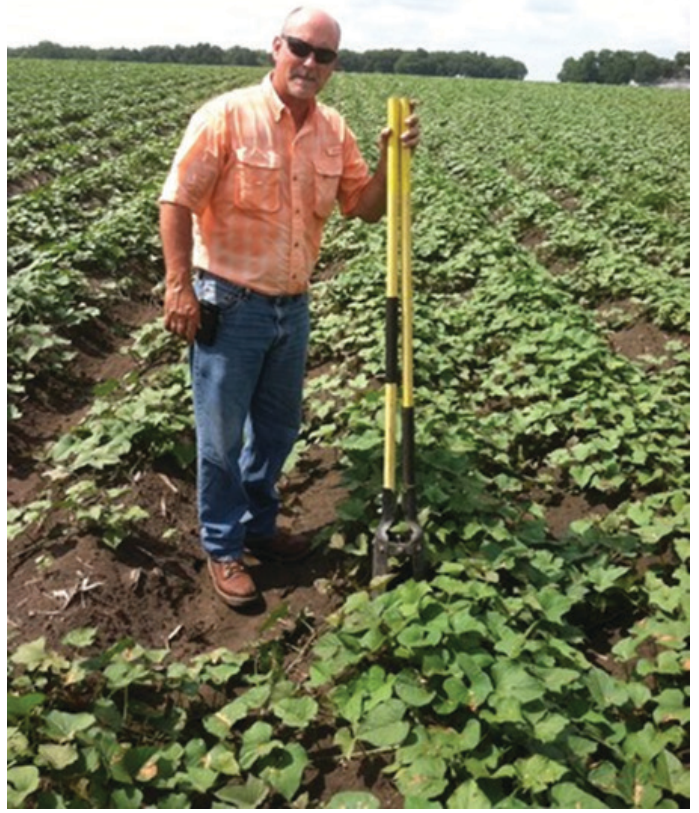

Figure 7. Selecting a sampling location and using a post hole digger to create a hole for the seed-bait.

Credits: R. Hochmuth, UF/IFAS

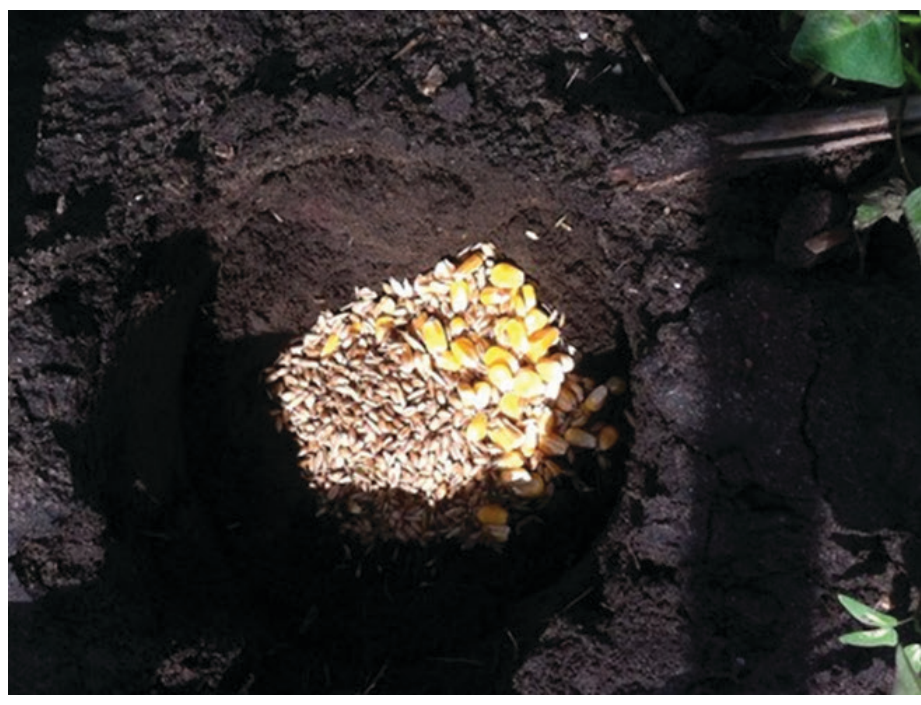

Figure 8. Position of the seed-bait mixture in the hole. Credits: R. Hochmuth, UF/IFAS

The seed-bait traps were removed after 2-3 weeks, and the soil-germinated grain seeds were sifted on a screen with or without rinse water to collect the wireworms (Figure 9). This method was effective when used in the fall but not after cold temperatures caused the wireworms to burrow more than 4 inches into the soil to overwinter. The presence of wireworms in the seed-bait traps during the fall indicated a risk of wireworm damage to a sweet potato crop if one were planted the following spring. The seed-bait trap system also can be used in the spring at least one month before sweet potatoes are to be planted, if the soil temperature has risen sufficiently for wireworm activity.

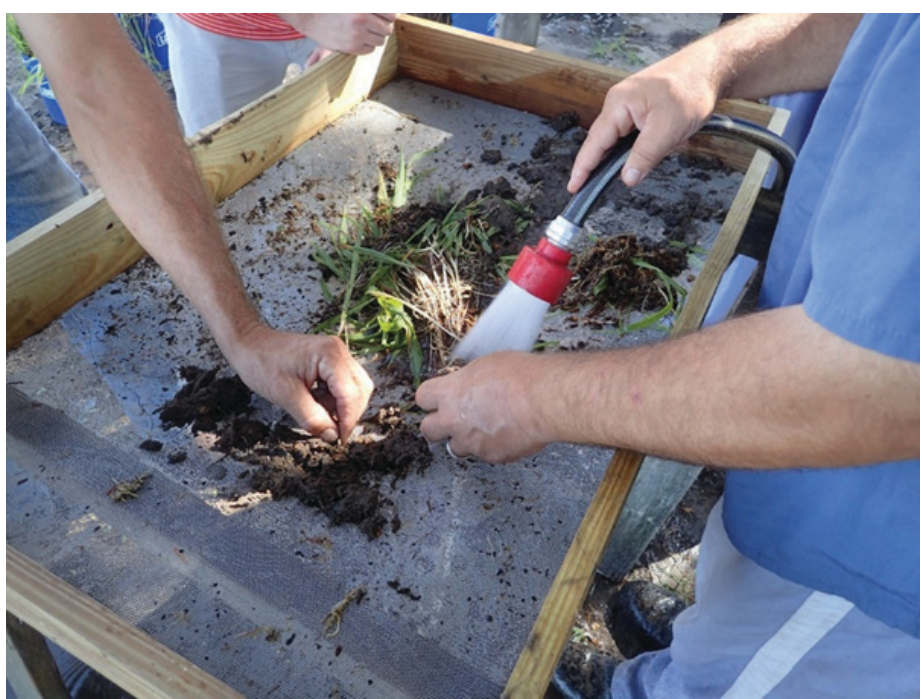

Figure 9. Sifting wireworms from seed-bait trap samples recovered from the field.

Credits: R. Hochmuth, UF/IFAS 


\section{Cultural Practices for Managing Wireworms}

Crop rotation and soil tillage affect the number of wireworms in a field prior to planting sweet potatoes. Sweet potato crops grown after corn or sorghum typically have higher populations of wireworms; however, a full assessment is needed to determine which crops result in more wireworms in north Florida. Preparing fields for planting in the fall by disking and plowing helps to kill wireworms by disturbance, desiccation, and physical damage. Fields should be tilled before establishing a winter cover crop. If possible, flooding a field for a week before planting can substantially decrease the wireworm population. Planting non-host crops after sweet potato and complete grass-free fallowing of a field also can significantly reduce wireworms.

\section{Chemical Control of Wireworms}

There are very few effective insecticides labeled in Florida for controlling wireworms in sweet potato crops. Research trials with insecticides applied to the soil before planting by NFREC-SV personnel in 2017 and 2018 confirmed that it is difficult to control wireworms with any labeled insecticides. Traditionally, soil-applied chlorpyrifos (Lorsban) has been preferred; however, it has become less effective, now requires a 125-day preharvest interval, and may no longer be available depending on the outcome of an EPA human health risk assessment. Other soil insecticides, such as ethoprop (Mocap), are labeled but have been inconsistently effective for controlling wireworms. Currently, the best strategy for using insecticides is to apply a soil insecticide before planting, followed by a foliar application of bifenthrin at lay-by before the last cultivation and vine cover of the beds. Even this practice can result in poor control, making wireworms clearly the most challenging insect pests to manage in sweet potatoes in Florida.

\section{Research on Entomopathogenic Nematodes for Managing Wireworms}

Entomopathogenic nematodes (EPNs) are microscopic roundworms that parasitize insects. EPNs harbor bacterial symbionts that eventually kill the insect host and provide a nutrient source for the nematodes to reproduce. EPNs are present in almost all terrestrial environments. Some EPNs are used as biological control agents to reduce the number of insect pests in agricultural systems. Species of EPNs have narrow ranges of insect hosts they can parasitize, resulting in limited impacts on non-target insects, including beneficial species, and other organisms. EPNs and their associated bacteria have no known effects on human health. Application of EPNs helps to reduce the number of harmful insects, resulting in increased plant vigor and health. Nematodes are easy to handle and can be applied in a liquid using standard pesticide spraying equipment. Success or failure of EPNs depends primarily on their host specificity and handling during transportation, storage, and application. However, EPNs are sensitive to some abiotic factors, including soil type, $\mathrm{pH}$, temperature, and exposure to sunlight. EPNs are most effective in sandy soils with $\mathrm{pH}$ ranging from 4 to 8 . When applying nematodes, the soil should be moist, and moisture should be maintained for at least eight hours. It is best to apply EPNs during the early morning or evening to minimize their desiccation and exposure to ultraviolet light. (https://entnemdept.ufl.edu/ creatures/nematode/entomopathogenic_nematode.htm).

A preliminary study to determine the efficacy and persistence of the commercially available EPN, Steinernema carpocapsae, was conducted in sweet potato fields in north Florida near NFREC-SV. After an application at the recommended rate, the nematodes reduced the number of wireworms in a field and feeding sites in the sweet potatoes during the early stage of storage root formation. However, even though there was a reduction in wireworm larval feeding due to the EPNs, the overall level of damage was still high and commercially unacceptable. Repeated applications of the nematodes in other fields did not increase wireworm control. EPNs can reproduce and persist on hosts in the soil long after they are applied; therefore, only one timely application may be required for maximum benefit. Further research is needed before recommending EPNs for managing wireworms.

\section{Research on Insecticides for Managing Wireworms}

Chlorinated hydrocarbon insecticides, such as chlordane, were commonly used to control soil insects because of their effectiveness, persistence, and low cost. Due to deregistration, most of those insecticides are no longer available for managing wireworms. The remaining insecticides are less effective and require precisely timed applications based on wireworm monitoring. Unfortunately, all of the current monitoring methods are time consuming and difficult to implement by commercial growers. Growers therefore routinely apply insecticides at preplant, plant, or post plant to maximize wireworm control for the duration of the crop. UF/IFAS faculty members conducted studies using 10 insecticide active ingredients to manage wireworms 
in 2017 and 2018 at NFREC-SV (https://doi.org/10.1093/ ee/nvaa113). The insecticide classes and trade names included the following: phenylpyrazole (Regent ${ }^{\circledast}$, fipronil), organophosphate (Aztec ${ }^{\circledR}$, tebupirimphos; Counter ${ }^{\circledR}$, terbufos; Lorsban ${ }^{\circledast}$, chlorpyrifos; Thimet ${ }^{\circledR}$, phorate; Mocap ${ }^{\oplus}$, ethoprop), neonicotinoid (Belay ${ }^{\oplus}$, clothianidin; Actara ${ }^{\oplus}$, thiamethoxam), pyrethroid (Force, tefluthrin), and botanical-type (Dazitol ${ }^{\mathrm{TM}}$, capsaicin and oleoresin of capsicum plus allyl isothiocyanate).

All insecticide treatments reduced wireworm feeding damage (deep, circular holes) by $34 \%-96 \%$ and $29 \%-73 \%$ in 2017 and 2018, respectively. Regent ${ }^{\circ}$ was the most effective insecticide for reducing wireworm feeding injury; however, it is not currently labelled for use in commercial sweet potato crops. Annual variations in the effectiveness of these insecticides would occur due to fluctuating environmental factors and cropping history of the sweet potato fields.

\section{Acknowledgement}

The authors would like to recognize the many UF/IFAS faculty, staff and students who helped with this project including: Peter DiGennaro, Chris Kerr, Alex Gannon, Ruhiyyih Dyrdahl-Young, Dustin Hart, Tim Norris, Ben Broughton, Mike Boyette, Dean Mobley, Jay Thompson, Jerry Butler, Wanda Laughlin, Dilcia Toro, Betsy Martin, Lei Lani Davis, and Zach Hill. In addition, appreciation is expressed to our farmer cooperators, Townsend Brothers Farms, and Starling Farms.

\section{Selected References}

Barsics, F., E. Haubruge, and F. Verheggen. 2013. "Wireworms' Management: An Overview of the Existing Methods, with Particular Regards to Agriotes spp. (Coleoptera: Elateridae)." Insects. 4:117-152. https://doi.org/10.3390/ insects 4010117

Bathon, H. 1996. "Impact of Entomopathogenic Nematodes on Non-target Hosts." Biocontrol Science and Technology. 6:421 - 434. https://doi.org/10.1080/09583159631398

Baumler, W. R., M. R. Abney, and G. G. Kennedy. 2010. "Survey of Wireworms (Coleoptera: Elateridae) in North Carolina Sweetpotato Fields and Seasonal Abundance of Conoderus vespertinus." Journal of Economic Entomology. 103:1268-1276.

Capinera, J. L. 2018. "Sweetpotato Weevil, Cylas formicarius (Fabricius) (Insecta: Coleoptera: Brentidae).” EDIS 2018 ENY-027. https://edis.ifas.ufl.edu/in154
Chalfant, R. B., R. K. Jansson, D. R. Seal, and J. M. Schalk. 1990. Ecology and Management of Sweet Potato Insects." Annual Review of Entomology. 35:157-180.

Dittmar, P. J., E. J. McAvoy, R. R. Smith, R. Raid, H. A. Smith, B. Wells, J. Beuzelin, et al. 2020. "2020-2021Vegetable Production Handbook of Florida: Chapter 15. Root Crop Production in Florida." EDIS 2020 (VPH) https://doi. org/10.32473/edis-cv300-2020

Dutta, B., T. Coolong, A. Hajihassani, A. Sparks, and S. Culpepper. 2018. "Sweet Potato Production and Pest Management in Georgia." University of Georgia Extension Bulletin 1489. https://extension.uga.edu/publications/ detail.html? number $=$ B1489\&title $=$ Sweet $\% 20$ Potato $\% 20$ Production\%20and\%20Pest\%20Management\%20in\%20 Georgia

Hammond, A. 2005. "Sweet Potato Insect Pest Management (IPM)." LSU AgCenter. https://extension.uga.edu/publications/detail.html? number $=$ B1489\&title $=$ Sweet $\% 20$ Potato $\% 20$ Production $\% 20$ and $\% 20$ Pest $\% 20$ Management $\% 20$ in $\% 20$ Georgia

Hue, S. M., and M. Y. Low. 2015. "An Insight into Sweet Potato Weevils Management: A Review.” Psyche: A journal of Entomology. https://doi.org/10.1155/2015/849560. https://www.hindawi.com/journals/psyche/2015/849560/ abs/

Seal, D., A. Baniya, R. Dyrdahl-Young, R. Hochmuth, N. Leppla, D. Fenneman, R. Broughton, and P. DiGennaro. 2020. "Wireworm (Coleoptera: Elateridae) Species Composition and Management in Sweet Potato Grown in North Florida Using Chemical Insecticides and Entomopathogenic Nematodes." Environmental Entomology. 49:1415-1426.

Seal, D. R., R. B. Chalfant, and M. R. Hall. 1992a. "Effectiveness of Different Seed Baits and Baiting Methods for Wireworms (Coleoptera: Elateridae) in Sweetpotato." Environmental Entomology. 21:957-963.

Seal, D. R., R. B. Chalfant, and M. R. Hall. 1992b. "Effects of Cultural Practices and Rotational Crops on Abundance of Wireworms (Coleoptera: Elateridae) Affecting Sweetpotato in Georgia." Environmental Entomology. 21:969-974.

Seal, D. R., R. McSorley, and R. B. Chalfant. 1992. "Seasonal Abundance and Spatial Distribution of Wireworms (Coleoptera: Elateridae) in Georgia Sweet Potato Fields." Journal of Economic Entomology. 85:1802-1808. 
Seal, D. R., and R. B. Chalfant. 1994. "Bionomics of Conoderus rudis (Coleoptera: Elateridae): Newly Reported Pest of Sweet Potato." Journal of Economic Entomology. 87:802-809.

Smith, T. P., and J. M. Beuzelin. 2014. "Insect Pest Management in Louisiana Sweet Potatoes." LSU AgCenter Pub.

2620. https://www.lsuagcenter.com/ /media/system/1/3/7 19/13796b134d6b107cfd23b06cb8703071/pub2620_pest_ sweet_potatoesmarch2015.pdf

Stock, S. P. 2015. "Diversity, Biology and Evolutionary Relationships," pp. 3-27. In Nematode Pathogenesis of Insects and Other Pests. Edited by R. Campos-Herrera. Cham: Springer International Publishing. https://doi. org/10.1007/978-3-319-18266-7_1

Webb, S. E. 2017. “Insect Management for Sweet Potato." EDIS 2002 (1) https://doi.org/10.32473/edis-ig159-2002

Willis, R. B., M. R. Abney, G. J. Holmes, J. R. Schultheis, and G. G. Kennedy. 2010. "Influence of Preceding Crop on Wireworm (Coleoptera: Elateridae) Abundance in the Coastal Plain of North Carolina." Journal of Economic Entomology. 103:2087-2093.

Zehnder, G. 1998. “A Sweet Potato Grower's Guide to Insect Pest Management." Alabama Cooperative Extension System ANR-1104. https://store.aces.edu/ItemDetail. aspx?ProductID=16505 